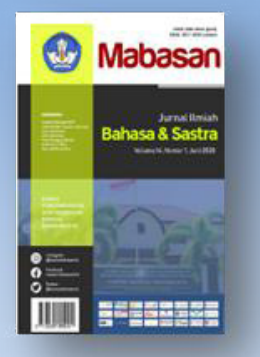

\title{
ANALISIS CAMPUR KODE OLEH TOKOH-TOKOH DALAM FILM LA HILA DONGGO KARYA ARY IPAN
}

\section{ANALYSIS OF CODE-MIXING USED BY CHARACTERS IN THE FILM LA HILA DONGGO BY ARY IPAN}

\author{
M. Busairi, Mintowati, Dianita Indrawati
}

Universitas Negeri Surabaya

Ponsel: 085337478346; Pos-el: mbusairi.19003@mhs.unesa.ac.id

\begin{abstract}
Abstrak
Campur kode dalam film tentu menarik untuk dikaji. Salah satunya film La Hila Donggo yang berasal dari Bima, diangkat dari cerita daerah setempat dengan memadukan unsur bahasa Bima dengan bahasa Indonesia serta memiliki nilai-nilai yang patut dipelajari. Penelitian ini bertujuan untuk mengetahui bentuk campur kode dalam film La Hila Donggo serta faktor penyebab terjadinya campur kode. Penulisan artikel ini menggunakan jenis penelitian deskriptif kualitatif dengan metode penelitian yang digunakan yaitu metode simak dan menggunakan teknik catat untuk memperoleh data lisan. Adapun analisis data menggunakan metode padan dengan menggunakan teknik hubung banding menyamakan. Langkah-langkah dalam analisis data yaitu, menampilkan data bentuk campur kode, menganalisis bentuk campur kode, mengklasifikasikan bentuk campur kode, menyamakan bentuk campur kode yang sesuai dengan artinya, dan menarik kesimpulan bentuk campur kode. Adapun hasil penelitian ini ditemukan 28 bentuk campur kode ke dalam mencakup kata 17 data seperti, ori,santabe, ina, nami, nahu, mada, nggomi, ompu. Kemudian frasa 7 data seperti, dou Donggo, dana Mbojo, ana mone, lenga mada. Selanjutnya, klausa 4 data seperti, hademu nahu lenga, lao nggomi, nahu eda, lembo ade ana. Selanjutnya, adapun faktor yang menyebabkan terjadinya campur kode yang terjadi dalam film La Hila Donggo meliputi, (a) faktor kebahasaan, (b) faktor kebiasaan, dan (c) faktor sikap penutur.
\end{abstract}

Kata kunci: campur kode; film La Hila Donggo

\begin{abstract}
It is always interesting to study code-mixing in the film. One of the film is La Hila Donggo which is based on a local story of Bima. The film contains combination of Bimanese language and Indonesian language with very valuable values. This study aims to determine the form of code-mixing in the film La Hila Donggo and the factors causinng the code-mixing. This is a descriptive qualitative research and the method used is the observation method. To obtain the the oral data, note taking techniques is
\end{abstract}


used. Then, the data is analyzed by the equivalent method with the comparative equate link technique. The steps of data analysis are presenting the code-mixing data, analyzing the code mixing forms, classifying the code mixing forms, equating the code mixing forms based on their meanings, and making conclusion of the code-mixing forms. Results of this study show that there are 28 forms of code-mixing that constitute 17 words form such as, ori, santabe, ina, nami, nahu, mada, nggomi, ompu and 7 phrases form such as, dou Donggo, dana Mbojo, ana mone, lenga mada and finally 4 clause form such as, hademu nahu lenga, lao nggomi, nahu eda, lembo ade ana. The factors causing code-mixing in the film La Hila Donggo include, (a) linguistic factors, (b) habit factors, and (c) speakers' attitude factors.

Keywords: Code-Mixing; La Hila Donggo Film

\section{Pendahuluan}

Dalam kehidupan sehari-hari bahasa merupakan sebagai alat komunikasi sosial, hubungan antara bahasa dan masyarakat pun tidak dapat dipisahkan. Hal ini karena bahasa sebagai alat untuk berinteraksi. Oleh karena itu, kita sebagai makhluk sosial yang saling membutuhkan perlu adanya komunikasi dalam bekerja sama antara satu dengan yang lain menggunakan bahasa.

Perlu kita ketahui bahwa masyarakat Indonesia pada umumnya masyarakat bilingual, artinya mampu menguasai dan menggunakan dua bahasa sekaligus yaitu bahasa Ibu (bahasa daerah) dan bahasa Nasional (bahasa Indonesia). Kemampuan seseorang menguasai dua bahasa dalam ilmu sosiolinguistik biasa disebut kedwibahasaan atau bilingualisme. Penguasaan bahasa tersebut dapat memperluas variasi bahasa baik bahasa tulis maupun bahasa lisan, termasuk di dalamnya adalah penggunaan atau pemakaian kata, frasa, klausa, idiom, sapaan, dan lain sebagainya.

Bilingualisme terjadi karena adanya kontak bahasa dalam masyarakat tutur sehingga menyebabkan peristiwa alih kode dan campur kode. Peristiwa campur kode tidak hanya terjadi dalam kehidupan nyata melainkan juga terjadi dalam komunikasi lisan atau percakapan (dialog) antartokoh dalam karya seni termasuk dalam film maupun dalam karya sastra seperti novel, cerpen, maupun puisi. Salah satunya peristiwa campur kode dalam film seperti yang terdapat pada film yang ada di tanah air menggunakan bahasa daerah dengan mencampurkan bahasa Indonesia maupun menggunakan bahasa Indonesia dengan bahasa asing. Hal tersebut ada pada salah satu film karya anak bangsa yang berasal dari Bima. Film ini diangkat berdasarkan cerita daerah setempat yang sangat terkenal judul filmnya La Hila 
Donggo di sutradarai oleh Ary Ipan dan penulis naskah Aan Saputra.

Dalam film tersebut sering kali terdapat penggunaan campur kode dialog oleh para pemain atau pemeran film tersebut dengan menggunakan dua bahasa yaitu bahasa daerah (bahasa Bima) dengan bahasa Indonesia. Penulis cerita sendiri melakukan campur kode untuk mengambarkan cerita kepada penonton, sehingga terjadi biligualisme yang mempengaruhi karya filmnya. Peristiwa campur kode bukan hanya pada film La Hila Donggo.

Sepengetahuan peneliti, banyak film di tanah air yang juga melakukan campur kode dalam karya filmnya, baik itu campur kode bahasa daerah dengan bahasa Indonesia maupun campur kode bahasa Indonesia dengan bahasa asing. Peristiwa campur kode dalam film seperti Assalamualaikum Beijing, Stupid Boss, Negeri 5 Menara, Yowis Ben, dan masih banyak lagi film lainnya yang menggunakan campur kode.

Pemilihan film La Hila Donggo sebagai objek penelitian berdasarkan beberapa alasan. Pertama, film La Hila Donggo diangkat dari cerita daerah Bima yang sangat terkenal. Kedua, cerita film La Hila Donggo ditulis oleh salah satu musisi terkenal di Bima yang juga sering menulis cerita rakyat Bima yang banyak disukai oleh penggemarnya dari hasil karya-karyanya. Ketiga, penulis cerita merupakan seorang bilingual yang mampu menguasai dua bahasa yaitu bahasa Bima sebagai bahasa pertama dan bahasa Indonesia sebagai bahasa kedua. Keempat, film La Hila Donggo berdasarkan hasil temuan peneliti, penulis sering memunculkan beberapa peristiwa campur kode yaitu bahasa daerah (bahasa Bima) dengan bahasa Indonesia antartokoh.

Film La Hila Donggo yang disutradarai oleh Ary Ipan dan penulis naskah Aan Saputra merupakan film diangkat dari cerita daerah Bima yang sangat terkenal. Cerita La Hila juga diangkat menjadi novel oleh Alan Malingi sastrawan Bima yang juga sangat dikenal oleh masyarakat Bima. Terciptanya film La Hila Donggo merupakan wujud sebagai pengenalan bahasa daerah kepada daerah lain dan juga sebagai wujud pelestarian bahasa daerah melalui karya film. Adapun tujuan dari penelitian ini untuk mengetahui dan mendeskripsikan bentuk campur kode yang ada dalam film La Hila Donggo. Oleh karena itu, peneliti sangat tertarik untuk menganalisis tentang fenomena campur kode dalam film terlebih film 
tersebut diangkat dari cerita daerah Bima dan film pun belum pernah diteliti oleh peneliti lain.

\section{Landasan Teori}

Penggunaan sumber referensi atau acuan pada penulisan artikel ini menjadi syarat dan pegangan bagi penulis dalam menentukan arah tulisan serta kualitas tulisan yang dihasilkan oleh penulis. Adapun penulisan artikel ini bersumber dari hasil penelitian dengan menggunakan beberapa landasan teori yang berkaitan dengan topik penulisan artikel. Adapun landasan teori sebagai berikut.

\subsection{Sosiolinguistik}

Sosiolinguistik merupakan bidang ilmu antardisiplin yaitu gabungan antara ilmu sosiologi dan ilmu linguistik. Dua bidang ilmu empiris tersebut mempunyai hubungan yang sangat erat. Oleh karena itu, untuk memahami apa itu sosiolinguistik perlu kita ketahui terlebih dahulu apakah sosiologi dan linguistik. Tentang ilmu sosiologi banyak batasan yang telah dikemukakan oleh para sosiolog yang sangat bervariasi. Ilmu sosiologi merupakan ilmu yang mengkaji secara objektif dan ilmiah mengenai hubungan manusia dalam kehidupan bermasyarakat, sedangkan linguistik atau bidang ilmu bahasa adalah bidang ilmu yang meneliti bahasa atau bidang ilmu yang mengkaji bahasa sebagai fokus objek kajian penelitiannya. Sosiolinguistik merupakan bidang ilmu yang mempelajari serta mengkaji aspekaspek kemasyarakatan bahasa, khususnya mengenai perbedaan penggunaan variasi bahasa yang terdapat dalam masyarakat yang berkaitan dengan faktor-faktor dalam masyarakat tersebut (Nababan, 1984). Sejalan dengan pendapat tersebut, Bram dan Dickey dalam (Ohoiwutun, 2002) menyatakan bahwa sosiolinguistik merupakan suatu bidang ilmu yang mengkaji bagaimana fungsi bahasa dalam kegiatan interaksi sosial sehari-hari. Bram dan Dickey menyatakan pula bahwa bidang ilmu sosiolinguistik berupaya untuk mendeskripsikan fenomena kemampuan masyarakat dalam menggunakan aturan-aturan bahasa atau norma dalam berbahasa secara tepat sesuai dengan situasi dan kondisi yang bervariasi yang ada dalam masyarakat. Selain itu, ilmu sosiolinguistik mengkaji bagaimana penutur bahasa berbicara secara berbeda sesuai dalam konteks sosial yang berbeda pula (Holmes, 2001). Ilmu sosiolinguistik memfokuskan pula kajiannya pada pengidentifikasian bagaimana fungsi-fungsi bahasa dan 
penggunaan bahasa yang digunakan oleh masyarakat dalam beriteraksi sosial. Ilmu sosiolinguistik merupakan gabungan dua ilmu atau biasa disebut antardisiplin seperti yang dijelaskan ahli lain, bahwa sosiolinguistik adalah suatu bidang ilmu antardisiplin yang mengkaji bahasa tentang bagaimana fungsi dari penggunaan bahasa itu sendiri di dalam interaksi sosial masyarakat (Chaer, Abdul. \& Agustina, 2010).

Dari hal di atas, tiga yang menjadi tolak ukur kajian ilmu sosiolinguistik yaitu: bahasa, masyarakat, dan kaitannya antara bahasa dengan masyarakat. Oleh karena itu, penulis dapat mengambil kesimpulan bahwa ilmu sosiolinguistik adalah bidang ilmu yang berfokus pada kajian bahasa sebagai gejala budaya yang terjadi pada masyarakat. Selain itu, ilmu sosiolinguistik merupakan ilmu mengkaji bahasa berkaitan dengan penutur bahasa karena bahasa sebagai bagian dari kehidupan masyarakat. Oleh karena itu, bagaimana bahasa digunakan dalam berinteraksi sosial antara individu satu dengan individu lain, bertukar gagasan, pendapat, maupun ide-ide antara masyarakat penutur bahasa lainnya.

\subsection{Bilingualisme}

Fenomena bilingualisme atau penggunaan dua bahasa oleh penutur bahasa banyak terdapat dalam berbagai bentuk aktivitas kehidupan masyarakat. Hal ini bisa kita ketahui misalnya, seorang penutur bahasa yang menggunakan dua bahasa yang berbeda dipengaruhi oleh latar belakang, situasi serta kondisi. Bahasa berfungsi sebagai alat komunikasi sosial, tentunya sangat berperan penting dalam hubungan antarindividu, antardaerah maupun antarnegara. Oleh karena itu, memelajari bahasa lain demi kepentingan hubungan sosial baik antardaerah atau antarnegara yang dinilai sebagai kebutuhan. Dengan demikian, hal ini memungkinkan suatu masyarakat dapat menguasai lebih dari satu bahasa. Masyarakat tutur yang terbuka artinya masyarakat yang memiliki kaitan dengan masyarakat tutur lainnya dalam kegiatan komunikasi atau interaksi sosial. Dari hal tersebut tentunya akan terjadi fenomena yang biasa kita kenal dalam ilmu sosiolinguistik ialah kontak bahasa sehingga melahirkan segala fenomena kebahasaan sebagai akibat adanya kontak bahasa antara masyarakat bahasa. Peristiwa kebahasaan tersebut di antaranya kedwibahasaan, diglosia, alih kode, serta campur kode. Salah satu peristiwa kebahasaan ialah kedwibahasaan yang biasa disebut juga dengan bilingualisme. Bilingualisme 
merupakan penggunaan serta penguasaan dua bahasa yang sama baiknya oleh penutur penutur bahasa atau kelompok masyarakat bahasa dalam kehidupannya dengan orang lain secara bergantian.

Bilingualisme merupakan penguasaan dalam menggunakan dua bahasa yakni penguasaan bahasa pertama dan penguasaan bahasa kedua oleh penutur bahasa dalam berinteraksi sosial (R, Kunjana, 2001). Penguasaan bahasa tersebut dapat memperluas variasi bahasa baik bahasa tulis maupun bahasa lisan.

Selain itu, menurut Fishman dalam (Chaer, Abdul. \& Agustina, 2010), bahwa bilingualisme adalah praktik dalam menggunakan dua bahasa secara bergantian oleh penutur bahasa atau kelompok masyarakat, dari bahasa yang satu ke bahasa yang lain dalam kegiatan berkomunikasi (Chaer, Abdul. \& Agustina, 2010). Penggunaan dua bahasa tersebut dilakukan secara aktif maupun pasif oleh penutur bahasa. Menurut Fishman tersebut, berbicara fenomena kedwibahasan atau bilingualisme memiliki beberapa cakupan peristiwa lainnya seperti, masalah tingkat, fungsi, alih kode, campur kode, interferensi, dan integrasi. Menurut Bloomfield dalam (Wahyudin, 2012), bahwa bilingualisme adalah penguasaan oleh seseorang dalam menggunakan dua bahasa yang sama baiknya seperti penguasaan penutur asli bahasa tersebut. Dalam hal ini, seorang bilingual mampu berbahasa atau berkomunikasi layaknya penutur asli. Selanjutnya, kemampuan seseorang serta kebiasaan dalam menuturkan dua bahasa secara baik dalam pergaulan sehari-hari merupakan peristiwa bilingualisme (Warsiman, 2014). Penggunaan dua bahasa ini bisa terjadi pada aktivitas berbicara maupun menulis. Adanya pengunaan dua bahasa secara bergantian tersebut akibat kontak bahasa pada masyarakat yang memiliki bahasa yang berbeda.

Sementara itu, menurut pendapat lain bilingualisme merupakan penguasaan bahasa oleh seseorang dengan kemampuan yang sama baiknya terhadap dua bahasa atau lebih (Erinyanti, R, W, Syarifuddin, T, K., Datoh, K., \& E, 2020). Dalam hal ini, penguasaan bahasa pertama oleh penutur kemudian mampu berkomunikasi juga dengan bahasa kedua yang dikuasainya secara bergantian.

Oleh karena itu, dari banyak pendapat di atas, penulis dapat menyimpulkan bahwa bilingualisme adalah kebiasaan dan kemampuan oleh seseorang atau kelompok masyarakat dalam berkomunikasi dengan 
menggunakan dua bahasa, yaitu bahasa pertama dengan bahasa kedua secara bergantian sesuai situasi dan kondisi, serta mampu menggunakan kedua bahasa tersebut hampir sama baiknya, baik dalam situasi tulis maupun lisan.

\subsection{Campur Kode}

Sebelum membahas campur kode, kita perlu ketahui dulu istilah kode. Kode merupakan bentuk untuk menyebut salah satu varian bahasa yang digunakan atau dipakai dalam berkomunikasi oleh masyarakat penutur bahasa. Pemodifikasian kode bahasa telah dianalisis untuk menentukan pola struktural adanya alih kode dan campur kode yang dominan di strata sosial yang berbeda (Hasan, 2015). Oleh karena itu, kode adalah suatu sistem bahasa dalam masyarakat untuk menentukan pola struktur bahasa yang dituturkan.

Campur kode merupakan digunakannya dua bahasa atau lebih, atau dua varian dari sebuah bahasa dalam satu masyarakat tutur. Peristiwa campur kode merupakan salah satu masalah yang ada dalam fenomena biligualisme yang lazim terjadi pada seseorang di dalam masyarakat yang multilingual maupun bilingual terhadap kontak bahasa itu terjadi.
Dalam hal ini, di dalam campur kode ada sebuah kode utama atau kode dasar yang digunakan dan memiliki fungsi dan keotonomiannya, sedangkan kode-kode yang lain terlibat dalam peristiwa tutur itu hanyalah serpihanserpihan saja, tanpa fungsi atau keotonimian sebagai kode (Chaer, Abdul \& Agustina, 2010). Misanya, dalam komunikasi dengan menggunakan bahasa Indonesia banyak menyelipkan serpihanserpihan bahasa Bima, bisa dikatakan hal ini telah terjadi campur kode.

Pada masyarakat Indonesia, campur kode ini sering sekali terjadi pada situasi seperti saat orang-orang berbincangbincang, bahkan dilakukan pada penciptaaan sebuah karya sastra maupun film. Campur kode yang yang biasa dilakukan ialah bahasa Indonesia dan bahasa daerah karena pada umumnya masyarakat Indonesia mampu menguasai dua bahasa tersebut. Peristiwa campur kode biasanya terjadi dalam kondisi dan situasi yang santai atau kegiatan komunikasi nonformal. Dalam situasi berbahasa yang formal pun jarang sekali terjadi peristiwa campur kode baik itu campur kode ke dalam maupun keluar, kalaupun hal itu terjadi hanya sebagai akibat dari tidak adanya padanan-padanan kata yang sesuai dengan bahasa yang 
digunakan atau dituturkah oleh seseorang. Peristiwa campur kode terjadi karena penutur bahasa mencoba menyelipkan beberapa unsur bahasa lain ke dalam bahasa tertentu ketika sedang komunikasi atau berinteraksi sosial (Sumarsono, 2002). Hal tersebut merupakan penggunaan dua bahasa atau dua variasi bahasa dari sebuah bahasa dalam suatu masyarakat tutur atau oleh seseorang dalam berkomunikasi atau interaksi sosial (Chaer, Abdul. \& Agustina, 2010).

Penggunaan campur kode tersebut merupakan sisipan unsur-unsur yang berasal dari beberapa bahasa yang dikuasai penutur. Selain itu, campur kode merupakan penggunaan satuan bahasa yang dilakukan oleh seseorang dari satu kode bahasa ke kode bahasa lainnya sebagai upaya dalam memperluas gaya bahasa, ragam, atau variasi bahasa oleh penutur termasuk di dalamnya penggunaan kata, frasa, klausa, idiom, dan sapaan (Kridalaksana, 2011). Berdasarkan beberapa pernyataan di atas, dapat penulis simpulkan bahwa campur kode adalah fenomena dalam menggunakan satuan bahasa atau unsurunsur kode bahasa yang satu ke dalam suatu bahasa yang lain atau fenomena mencampurkan bahasa dalam suatu interaksi sosial oleh penutur bahasa atau kelompok masyarakat tutur. Sesuai dengan kesimpulan tersebut, keterkaitan teori campur kode yang digunakan dalam peneliti bahwa penelitian ini mencakup campur kode bahasa Bima ke dalam bahasa Indonesia yang terdapat pada film La Hila Donggo, yang merupakan bahasa sehari-hari bagi masyarakat di Kabupaten Bima dan Kabupaten Dompu.

\subsubsection{Macam-Macam Campur Kode}

Berdasarkan pembahasan di atas, selanjutnya adapun macam-macam campur kode sesuai dengan unsur bahasa serapan yang dapat menimbulkan fenomena campur kode. Terdapat tiga macam campur kode menurut Jendra dalam (Padmadewi, 2014) sebagai berikut.

a. Campur Kode ke Luar (outer code mixing)

Campur kode ke luar merupakan campur kode yang dilakukan oleh penutur bahasa dengan menyerap unsur-unsur bahasa asing lainnya seperti, dalam pemakaian bahasa Indonesia terdapat sisipan unsur dari bahasa asing seperti bahasa Arab, bahasa Jepang, bahasa Inggris, bahasa Jerman, dan lain sebagainya. Adapun contoh campur kode ke luar yaitu, "Good morning, temanteman". Kalimat tersebut menunjukkan adanya campur kode ke luar karena 
terdapat frasa dari bahasa Inggris. Oleh karena itu, teori campur kode ke luar tidak terkait dengan penelitian penulisan artikel ini karena subjek yang diteliti adalah campur kode bahasa Bima kedalam bahasa Indonesia pada film La Hila Donggo.

b. Campur Kode ke Dalam (inner code mixing)

Campur kode ke dalam merupakan campur kode yang menyerap unsur-unsur bahasa daerah atau sebaliknya dengan segala variasinya yang masih sekerabat misalnya, dalam peristiwa campur kode tuturan bahasa Indonesia dengan bahasa Bima, atau sebaliknya bahasa Bima dengan bahasa Indonesia. Adapun contoh campur kode ke dalam yaitu, Lenga, Ayo Kita Pergi Di Tolo. Pada kalimat tersebut menunjukkan adanya campur kode ke dalam karena terdapat kata dari bahasa Bima. Oleh karean itu, teori campur kode ke dalam terkait dengan penelitian penulisan artikel karena subjek yang diteliti adalah campur kode bahasa Bima ke dalam bahasa Indonesia dalam film La Hila Donggo.

\section{c. Campur Kode Campuran (hybrid code mixing)}

Campur kode campuran merupakan campur kode yang sudah menyerap unsur bahasa lainnya seperti bahasa daerah (bahasa Bugis, Sunda, Melayu, Jawa) maupun bahasa asing (bahasa Jepang, Jerman, Inggris, China). Dalam hal ini, campur kode campuran bisa mencampurkan beberapa bahasa sekaligus seperti mencampurkan antara bahasa daerah, bahasa Indonesia, dan bahasa asing dalam suatu interaksi sosial. Oleh karena itu, teori campur kode campuran tidak terkait dengan penelitian penulisan artikel ini karena subjek yang diteliti adalah campur kode bahasa Bima ke dalam bahasa Indonesia dalam film La Hila Donggo.

\subsubsection{Bentuk-Bentuk Campur Kode}

Fenomena campur kode tentu memiliki jenis dan bentuknya. Oleh karena itu, teori tentang bentuk-bentuk campur kode yang ada dalam penulisan artikel ini diambil dari teori Jendra dalam (Suandi, 2014) yang membagi bentuk campur kode menjadi beberapa bentuk yaitu campur kode tataran kata, campur kode tataran frasa dan campur kode tataran klausa. Adapun penjelasan bentuk-bentuk campur kode tersebut sebagai berikut.
a. Campur Kode pada Tataran Kata
Kata merupakan satuan bahasa yang dianggap sebagai satuan terkecil yang dapat berdiri sendiri dan menduduki salah satu fungsi dari hierarkir sintaksis. Kata 
ialah satuan bahasa yang terkecil yang dapat membentuk suatu kalimat (Chaer, 2008). Dalam hal ini, fenomena campur kode pada tataran kata merupakan bentuk campur kode yang banyak digunakan oleh penutur dalam hubungan interaksi sosial baik dalam lisan maupun tulisan. Berikut contoh campur kode berwujud kata.

Makanya, nggomi jangan lupa dengan nasihat ibu di rasa.

Contoh kalimat di atas yang bercetak tebal merupakan campur kode pada tataran kata yang ada dalam kalimat bahasa Indonesia kemudian disisipkan kata bahasa Bima yaitu kata nggomi dan rasa. Kata nggomi dalam bahasa Bima bermakna 'kamu' sedangkan rasa dalam bahasa Bima bermakna 'kampung'. Adapun contoh tersebut berarti makanya, kamu jangan lupa dengan nasihat ibu di kampung.

b. Campur Kode pada Tataran Frasa

Frasa merupakan satuan dari gramatikal yang terdiri dari dua kata yang tidak melebihi batas fungsi klausa atau satuan gramatikal yang tidak berpredikat (nonpredikatif). Dalam hal ini, campur kode pada tataran frasa merupakan satuan sintaksis yang terdapat setingkat di bawah klausa dan setingkat di atas kata. Berikut contoh campur kode berwujud frasa.
Tolu mbua fo'o yang ingin kamu makan.

Contoh kalimat di atas yang bercetak tebal merupakan campur kode pada tataran frasa yang ada dalam kalimat bahasa Indonesia kemudian disisipkan frasa bahasa Bima yaitu tolu mbua fo'o bermakna 'Tiga buah mangga'. Adapun contoh tersebut berarti tiga buah mangga yang ingin kamu makan.

\section{c. Campur Kode pada Tataran Klausa \\ Klausa merupakan sebuah rangkaian} kata ataupun frasa yang mengandung subjek dan predikat atau hanya predikat saja yang berpotensi untuk menjadi kalimat (Firman, 2016). Berikut adalah contoh campur kode pada tataran klausa.

Nahu kanangi karena hubungan kita berakhir.

Berdasarkan contoh kalimat di atas yang bercetak tebal merupakan bentuk campur kode klausa karena mengandung sisipan dari klausa bahasa Bima yaitu Nahu kanangi yang bermakna 'Saya menangis'. Adapun contoh tersebut berarti saya menangis, karena hubungan kita berakhir.

\section{Metode Penelitian}

Metode penelitian ialah suatu cara dalam memecahkan sebuah masalah penelitian yang dilakukan berdasarkan 
perencanaan yang cermat untuk mendapatkan fakta serta kesimpulan. Adapun jenis penelitian yang digunakan adalahpenelitian deskriptif kualitatif.

Penelitian deskriptif kualitatif merupakan salah satu jenis penelitian yang digunakan untuk mendeskripsikan atau menggambarkan suatu fenomena tentang apa yang dialami oleh subjek penelitian misalnya perilaku, persepsi, motivasi, tindakan dan lain-lainya (Astripona, M., Madeten, S. S., \& Amir, 2020). Artinya, hasil penelitian ini dideskripsikan sesuai fakta yang ada yaitu berupa bahasa lisan, kemudian dianalisis dan ditafsirkan secara objektif lalu dideskripsikan dalam bentuk kata-kata dan bahasa. Sesuai dengan metode penelitian yang digunakan, penelitian ini bertujuan untuk menganalisis peristiwa campur kode yang terdapat dalam film La Hila Donggo.

Adapun data yang digunakan dalam penelitian ini adalah bentuk campur kode dalam film La Hila Donggo. Selanjutnya sumber data dalam penelitian ini berasal dari film La Hila Donggo yang diperoleh dari situs Youtube dengan cara mengunduhnya. Film La Hila Donggo merupakan film yang beraal dari daerah Bima Nusa Tenggara Barat disutradarai oleh Ary Ipan dan penulis naskah Aan Saputra. Film La Hila Donggo dirilis pada tahun 2019 dengan jumlah durasi 1 jam 25 menit.

Pengumpulan data penelitian ini dilakukan menggunakan metode simak. Metode simak dilakukan untuk menyimak penggunaan bahasa. Istilah menyimak disini tidak hanya berkaitan dengan penggunaan bahasa secara lisan, tetapi juga penggunaan bahasa secara tertulis (Mahsun, 2005). Metode ini digunakan untuk mendapatkan data lisan, yaitu data berupa campur kode yang terjadi dalam film La Hila Donggo.

Metode simak dalam penelitian ini menggunakan teknik lanjutan berupa teknik catat. Teknik catat digunakan sebagai teknik dalam pengumpulan data. Teknik catat adalah mencatat beberapa bentuk yang relevan bagi penelitiannya dari penggunaan bahasa secara tertulis (Mahsun, 2005). Adapun langkah-langkah dalam pengumpulan data penelitian yaitu.

1) Mengunduh film La Hila Donggo di Youtube.

2) Menonton film La Hila Donggo.

3) Mencatat semua dialog antartokoh yang mengandung campur kode yang terjadi yang diperoleh dari sumber data, yaitu film La Hila Donggo. 
Selanjutnya, langkah-langkah analisis data yang dilakukan dalam penelitian ini yaitu menggunakan metode padan. Ada dua metode utama yang dapat digunakan dalam analisis data, yaitu metode padan intralingual dan padan ekstralingual (Mahsun, 2005). Metode padan intralingual adalah metode analisis dengan cara menghubung-bandingkan unsur-unsur yang bersifat lingual, baik yang terdapat dalam satu bahasa maupun dalam beberapa bahasa yang berbeda. Dalam hal ini, Metode padan menggunakan teknik hubung banding menyamakan (HBS) dan hubung banding membedakan (HBB). Oleh karena itu, penulisan artikel ini menggunakan teknik hubung banding menyamakan antara bahasa Bima dan bahasa Indonesia dalam dialog film La Hila Donggo.

Selanjutnya, peneliti menggunakan teknik catat pada kartu data yang dilanjutkan pada klasifikasi data. Setelah pencatatan dilakukan peneliti melakukan klasifikasi atau pengelompokan jenis campur kode. Adapun langkah analisis data sebagai berikut:

1) mengidentifikasi data percakapan yang mengandung campur kode peradegan film.
2) menganalisis bentuk campur kode yang dilakukan oleh tokoh-tokoh dalam film menurut Jendra.

3) mengklasifikasikan bentuk campur kode antartokoh dalam film La Hila Donggo ke dalam jenis-jenis campur kode.

4) menyamakan bentuk campur kode bahasa Bima dan bahasa Indonesia yang sesuai dengan artinya.

5) menarik kesimpulan bentuk-bentuk campur kode yang dilakukan oleh tokoh-tokoh dalam film La Hila Donggo.

\section{Pembahasan}

Sesuai dengan teori yang digunakan, penelitian campur kode yang digunakan dalam film La Hila Donggo yaitu bentuk campur kode ke dalam (inner code mixing) dengan menyisipkan bahasa Bima ke dalam bahasa Indonesia. Selain itu, adanya faktor-faktor yang menyebabkan terjadinya campur kode tersebut. Adapun bentuk campur kode (inner code mixing) tersebut meliputi: (a) campur kode kata, (b) campur kode frasa, dan (c) campur kode klausa.

Adapun data-data penggalan dialog tokoh-tokoh dalam film La Hila Donggo berdasarkan bentuk campur kode ke 
dalam (inner code mixing) sebagai berikut.

\subsection{Campur Kode Berdasarkan Bentuk}

\subsubsection{Kata}

1) Nuki: "Dia tidak tahu Ori, kenapa marah-marah sama dia. Dia masih kecil $\boldsymbol{O r i}$, tidak seharusnya $\boldsymbol{O r i}$ membentak anak kecil”. (menit 07:54 $--08: 06)$

Berdasarkan penggalan data dialog di atas, terdapat bentuk campur kode kata yang dilakukan oleh tokoh Nuki. Penyisipan tersebut terdapat pada kata 'Ori' kata yang berasal dari bahasa Bima yang berarti 'paman'. Adapun fungsi dari campur kode tersebut ialah panggilan untuk menghormati lawan tuturnya.

2) Hila: "Santabe. Ayo kita mandi bersama di sini".

Inge: "Tidak usah lenga biar kami mandi di sana saja. Kami tidak ingin mengganggu kalian yang sedang bersenda gurau. Santabe". (menit 09:21--09:35)

Berdasarkan penggalan data dialog di atas, terdapat bentuk campur kode kata yang dilakukan oleh tokoh Hila. Penyisipan tersebut terdapat pada kata 'Santabe' kata yang berasal dari bahasa Bima yang berarti 'permisi'. Adapun fungsi dari campur kode tersebut ialah untuk mempertegas sesuatu dengan mengungkapkan permintaan izin lawan tuturnya. Selain itu, bentuk camur kode juga dituturkan oleh tokoh Inge yang terdapat pada kata 'lenga', kata yang berasal dari bahasa Bima yang berarti 'teman'. Fungsi dari campur kode tersebut ialah untuk memanggil lawan tutur alias temannya tanpa menyebutkan namanya tersebut. Serta tokoh Inge melakukan penyisipan campur kode pada kata "Santabe' kata yangberasal dari bahasa Bima yang berarti 'permisi'. Fungsi dari campur kode tersebut ialah untuk mempertegas sesuatu dengan mengungkapkan permintaan izin atau berpamitan kepada lawan tuturnya.

3) Ince: "Iya benar. Ina ku juga bercerita seperti itu". (menit 13:28$13: 31)$

Berdasarkan penggalan data dialog di atas, terdapat bentuk campur kode kata yang dilakukan oleh tokoh Ince. Penyisipan tersebut terdapat pada kata 'Ina' kata yang berasal dari bahasa Bima yang berarti 'ibu'. Fungsi dari campur kode tersebut ialah untuk menyebutkan sapaan kepada perempuan yaitu ibu dari seorang anak.

4) Ince: "Mari kita saksikan mpa'a Ncala”. (menit 15:26--15:30) 
Berdasarkan penggalan data dialog di atas, terdapat bentuk campur kode kata yang dilakukan oleh tokoh Ince. Penyisipan tersebut terdapat pada kata 'mpa'a' kata yang berasal dari bahasa Bima yang berarti 'permainan'. Adapun fungsi dari campur kode yang dilakukan tokoh tersebut ialah untuk mengungkapkan sesuatu yang digunakan dalam bermain. Dalam hal ini, suatu permainan tradisional adu kekuatan yang berasal Bima yang dilakukan dua orang laki-laki.

5) Hila: "Teman-teman, terima kasih sudah menemani nahu".

Nihi: "Kenapa Hila berbicara seperti itu? Nami senang Hila.". (menit 18:03--18:19)

Berdasarkan penggalan data dialog di atas, terdapat bentuk campur kode kata yang dilakukan oleh tokoh Hila. Penyisipan tersebut terdapat pada kata 'nahu' kata yang berasal dari bahasa Bima yang berarti 'aku'. Fungsi daripada kata tersebut digunakan untuk mengungkapkan kata ganti orang pertama yang berbicara. Dalam hal ini termasuk ragam akrab yang digunakan pada teman sebaya. Selanjutnya campur kode dilakukan oleh tokoh Nihi yang terdapat pada kata 'nami'. Kata tersebut berasal dari bahasa Bima yang berarti 'kami.'
Adapun fungsi pada kata tersebut digunakan untuk orang yang berbicara dengan orang lain. Dalam hal ini, tokoh Nihi menggunakan kata tersebut kepada lawan tuturnya yaitu Hila.

6) Tengge: "Rupanya ini Nggomi sembunyikan dari nahu Selu”. (menit 20:16--20:22)

Berdasarkan penggalan data dialog di atas, terdapat bentuk campur kode kata yang dilakukan oleh tokoh Tengge. Penyisipan tersebut terdapat pada kata 'nggomi' dan 'nahu'. Dua kata tersebut berasal dari bahasa Bima yang berarti 'kamu' dan 'aku'. Fungsi dari dua kata tersebut sebagai kata yang dipakai untuk sapaan teman sebaya.

7) Tengge: “Mada ingin mencari masa depanku ina." (menit 23:21--23:25)

Berdasarkan penggalan data dialog di atas, terdapat bentuk campur kode kata yang dilakukan oleh tokoh Tengge. Penyisipan tersebut terdapat pada kata 'mada' dan kata 'Ina'. Kata tersebut yang berasal dari bahasa Bima yang berarti 'saya' dan 'ibu'. Fungsi dari campur kode kata 'mada' tersebut merupakan ragam hormat untuk orang yang lebih tua dari kita dan kata 'ina' ialah untuk menyebutkan sapaan kepada perempuan yaitu ibu dari seorang anak. 
8) Ina Tengge:'Ina ingin mengingatkan kembali petuah amamu yang mungkin sudah nggomi lupakan." (menit 23:46--23:51)

Berdasarkan penggalan data dialog di atas, terdapat bentuk campur kode kata yang dilakukan oleh tokoh Ina Tengge. Penyisipan tersebut terdapat pada kata 'ina', 'amamu' dan 'nggomi'. Kata tersebut yang berasal dari bahasa Bima yang berarti 'ibu', 'bapak' dan 'kamu'. Fungsi dari campur kode kata-kata tersebut merupakan bentuk sapaan dalam tuturan.

9) Tengge: "Mungkin ini sudah menjadi takdir mada." (menit 24:12--24:15)

Berdasarkan penggalan data dialog di atas, terdapat bentuk campur kode kata yang dilakukan oleh tokoh Tengge. Penyisipan tersebut terdapat pada kata 'mada' yang berasal dari bahasa Bima yang berarti 'saya'. Fungsi dari campur kode kata 'mada' tersebut merupakan ragam hormat untuk orang yang lebih tua dari kita.

10) Wai Kimpi: “Ompu kita sembunyikan la Hila di ladang dulu. Perasaan mada tidak enak ompu." (menit 24:28--24:36)

Berdasarkan penggalan data dialog di atas, terdapat bentuk campur kode kata yang dilakukan oleh tokoh Wai Kimpi.
Penyisipan tersebut terdapat pada kata 'ompu' dan 'mada' yang berasal dari bahasa Bima yang berarti 'kakek' dan 'saya'. Fungsi dari campur kode kata 'ompu' tersebut merupakan bentuk sapaan dan kata 'mada' merupakan ragam hormat untuk orang yang lebih tua dari kita.

11) Selu: "Ada la Tengge ina." (menit 26:35--26:37)

Berdasarkan penggalan data dialog di atas, terdapat bentuk campur kode kata yang dilakukan oleh tokoh Selu. Penyisipan tersebut terdapat pada kata 'Ina'. Kata tersebut yang berasal dari bahasa Bima yang berarti 'ibu'. Fungsi dari campur kode kata 'ina' ialah untuk menyebutkan sapaan kepada perempuan yaitu ibu dari seorang anak.

12) Tengge : "Jangan pernah menyentuh nahu." (menit 41:56--41:59)

Berdasarkan penggalan data dialog di atas, terdapat bentuk campur kode kata yang dilakukan oleh tokoh Tengge. Penyisipan tersebut terdapat pada kata 'nahu'. Kata tersebut berasal dari bahasa Bima yang berarti 'aku'. Fungsi dari kata tersebut sebagai kata yang dipakai untuk sapaan teman sebaya.

13) Selu: "Asal nggomi tahu." (menit 42:46--42:48) 
Berdasarkan penggalan data dialog di atas, terdapat bentuk campur kode kata yang dilakukan oleh tokoh Selu. Penyisipan tersebut terdapat pada kata 'nggomi'. Kata tersebut berasal dari bahasa Bima yang berarti 'kamu'. Fungsi dari kata tersebut sebagai kata yang dipakai untuk sapaan teman sebaya.

14) Wangge Wuri: "La mone ke sini." (menit 48:58--49:00)

Berdasarkan penggalan data dialog di atas, terdapat bentuk campur kode kata yang dilakukan oleh tokoh Wangge Wuri. Penyisipan tersebut terdapat pada kata 'mone'. Kata tersebut berasal dari bahasa Bima yang berarti 'laki-laki', namun dalam kehidupan sehari-hari bisa diartikan kakaknda. Fungsi dari kata tersebut sebagai kata sapaan yang lebih hormat.

\subsubsection{Frasa}

1) Selu: "Lagi pula ini sudah menjadi karakter kita sebagai dou Donggo.". (menit 11:37--11:41)

Berdasarkan penggalan data dialog di atas, terdapat bentuk campur kode frasa yang dilakukan oleh tokoh Selu. Penyisipan tersebut terdapat pada frasa 'dou Donggo' frasa tersebut berasal dari bahasa Bima yang berarti "orang Donggo". Fungsi frasa ini untuk menyebutkan sebuh nama suku atau daerah yang berada di Bima.

2) Ompu Tua: "Buka matamu ana mone." (menit 38:04--38:08)

Berdasarkan penggalan data dialog di atas, terdapat bentuk campur kode frasa yang dilakukan oleh tokoh Ompu Tua. Penyisipan tersebut terdapat pada frasa 'ana mone' frasa tersebut berasal dari bahasa Bima yang berarti "anak lakilaki”. Fungsi frasa ini sering diungkapkan orang tua atau ibu dalam memanggil serta menyebutkan selain nama asli anak lakilakinya.

3) Jama: "Lenga mada sendiri tuan." (menit 49:18--49:20)

Berdasarkan penggalan data dialog di atas, terdapat bentuk campur kode frasa yang dilakukan oleh tokoh Jama. Penyisipan tersebut terdapat pada frasa 'lenga mada' frasa tersebut berasal dari bahasa Bima yang berarti "teman saya". Fungsi frasa ini untuk mengungkapkan informasi memiliki seorang teman kepada lawan tutur yang lebih tua. Hal ini dilihat pada penggunaan kata 'mada' yang artinya 'saya' merupakan ragam hormat dalam bahasa Bima.

4) Nuhi: "Mboto-mboto kangampu Pangeran, kelihatannya sae sangat senang sekali. Sebenarnya ada apa sae?" (menit 51:58--52:08) 
Berdasarkan penggalan data dialog di atas, terdapat bentuk campur kode frasa yang dilakukan oleh tokoh Nuhi. Penyisipan tersebut terdapat pada frasa 'mboto-mboto kangampu' frasa tersebut berasal dari bahasa Bima yang berarti "banyak maaf". Fungsi frasa ini untuk diungkap untuk merendahkan diri kepada seseorang atau lawan tutur baik yang lebih tua maupun sebaya.

5) Jama: "Aku rasa ini bukan soal wanita saja lenga. Mungkin soal harga diri yang sudah melekat dalam darah kita sebagai dou Mbojo." (menit 53:32--53:40)

Berdasarkan penggalan data dialog di atas, terdapat bentuk campur kode frasa yang dilakukan oleh tokoh Jama. Penyisipan tersebut terdapat pada frasa 'dou Mbojo' frasa tersebut berasal dari bahasa Bima yang berarti "orang Bima”. Fungsi frasa ini sering diungkapkan ketika orang-orang Bima menyebutkan daerah asalnya.

6) Hila; "Ina, apa yang harus mada lakukan ina. Sepertinya dana Mbojo sudah tidak akur lagi." (menit $1: 01: 46--1: 01: 54)$

Berdasarkan penggalan data dialog di atas, terdapat bentuk campur kode frasa yang dilakukan oleh tokoh Hila. Penyisipan tersebut terdapat pada frasa 'dana Mbojo' frasa tersebut berasal dari bahasa Bima yang berarti "tanah Bima". Fungsi frasa ini sering juga diungkapkan ketika orang-orang Bima menyebutkan daerahnya.

7) Wai Kimpi: "Nggomi harus kuat ana siwe. Pasti Dewa Yang Agung memberikan satu pemuda untuk pendamping hidupmu kelak ana siwe." (menit 1:01:27--1:01:35)

Berdasarkan penggalan data dialog di atas, terdapat bentuk campur kode frasa yang dilakukan oleh tokoh Wai Kimpi. Penyisipan tersebut terdapat pada frasa 'ana siwe' frasa tersebut berasal dari bahasa Bima yang berarti "anak perempuan". Fungsi frasa ini sering diungkapkan orang tua atau ibu dalam memanggil serta menyebutkan selain nama asli anak perempuannya.

\subsubsection{Klausa}

1) Ina Tengge: "Sebenarnya lao nggomi hendak ke mana." (menit 23:21-23:25)

Berdasarkan penggalan data dialog di atas, terdapat bentuk campur kode klausa yang dilakukan oleh tokoh Ina Tengge. Penyisipan tersebut terdapat pada klausa 'lao nggomi' klausa tersebut berasal dari bahasa Bima yang berarti "kepergian kamu". Klausa tersebut diungkapkan oleh orang tua (ibu) kepada 
anaknya ketika buru-buru hendak ke suatu tempat.

2) Wai Kimpi:“Lembo ade ana, ya." (menit 35:55--35:58)

Berdasarkan penggalan data dialog di atas, terdapat bentuk campur kode klausa yang dilakukan oleh tokoh Wai Kimpi. Penyisipan tersebut terdapat pada klausa 'lembo ade ana' klausa tersebut berasal dari bahasa Bima yang berarti "tetap tabah anak". Fungsi klausa ini sering diucapkan orang-orang Bima ketika menghadapi atau diuji atas segala masalah dalam hidupnya agar tetap tabah dengan segala masalah yang dihadapi.

3) Jama : "Nahu eda la Hila ketakutan." (menit 45:10 --45:12)

Berdasarkan penggalan data dialog di atas, terdapat bentuk campur kode klausa yang dilakukan oleh tokoh Jama. Penyisipan tersebut terdapat pada klausa 'nahu eda' klausa tersebut berasal dari bahasa Bima yang berarti "saya melihat". Klausa ini diungkapkan ketika melihat seseorang atau sesuatu.

4) Selu: "Nggomi tega hademu nahu lenga." (menit 46:52--46:55)

Berdasarkan penggalan data dialog di atas, terdapat bentuk campur kode klausa yang dilakukan oleh tokoh Selu. Penyisipan tersebut terdapat pada klausa 'hademu nahu lenga' klausa tersebut berasal dari bahasa Bima yang berarti "membunuhku sahabat". Klausa ini diungkapkan seorang teman kepada sahabatnya yang tega membunuhnya.

\subsection{Faktor-Faktor Campur Kode}

Campur kode ialah peristiwa penyisipan suatu bahasa ke dalam bahasa yang lain oleh penutur bahasa. Ada berbagai macam faktor terjadinya campur kode bermacam-macam seperti, keterbatasan kata dalam bahasa Indonesia sehingga penutur menggunakan sisipan bahasa lain sebagai pengganti.

\subsubsection{Faktor Kebahasaan}

Penutur dalam menggunakan bahasanya sering berusaha untuk mencampurkan bahasanya dengan kode bahasa lain agar mempercepat penyampaian pesan. Terkait faktor kebahasaan yang menyebabkan campur kode ialah karena kesantaian atau dalam situasi informal juga karena keterbatasan bahasa.

Hila: "Teman-teman, terima kasih sudah menemani nahu".

Penggalan data dialog di atas terjadi pada situasi informal yaitu ketika tokoh Hila ingin mengucapkan terima kasih kepada temannya dengan menggunakan kata sapaan sesama sebaya. Adapun 
campur kode yang digunakan di atas yaitu bahasa Bima ke bahasa Indonesia.

\subsubsection{Faktor Kebiasaan}

Dalam faktor kebiasaan, penutur dalam campur kode bahasa yang digunakan akibat dari kebiasaan menggunakan bahasa dalam kehidupan sehari-hari sehingga memengaruhi interaksi sosialnya.

Wai Kimpi:“Lembo ade ana, ya.”

Penggalan data dialog di atas terjadi pada situasi informal, ketika orang tua memberikan kata penyemangat terhadap anaknya. Campur kode tersebut juga biasanya masyarakat Bima menggunakan dalam situasi formal. Adapun campur kode yang digunakan di atas yaitu bahasa bahasa Bima ke bahasa Indonesia.

\subsubsection{Faktor Sikap Penutur}

Seseorang penutur yang berlatar belakang menggunakan bahasa Bima yang memiliki sikap bahasa yang positif dan kadar kesetiaan yang tinggi terhadap bahasa Bima, sehingga ketika ia berbicara bahasa Indonesia tentu akan terjadi campur kode ke dalam. Selain itu, kurang mengusai bahasa Indonesia dengan baik.

Nuki: "Dia tidak tahu Ori, kenapa marahmarah sama dia. Dia masih kecil Ori, tidak seharusnya Ori membentak anak kecil”.
Penggalan data dialog di atas terjadi ketika tokoh Nuki tidak mengetahui bahasa Indonesia yaitu kata Ori yang berarti paman. Adapun campur kode yang digunakan di atas yaitu bahasa Bima ke bahasa Indonesia.

\section{Penutup}

Berdasarkan analisis dan pembahasan data hasil penelitian pada film La Hila Donggo karya Ary Ipan, maka peneliti dapat menyimpulkan bahwa bentuk campur kode yang ada pada film La Hila Donggo yaitu campurr kode ke dalam (inner code mixing). Campur kode tersebut merupakan campur kode yang menyerap unsurunsur bahasa daerah atau sebaliknya dengan segala variasinya yang masih sekerabat. Dalam film La Hila Donggo tersebut merupakan campur kode tuturan bahasa Bima ke dalam bahasa Indonesia.

Bentuk campur kode ke dalam (inner code mixing) tersebut meliputi: (a) campur kode kata, (b) campur kode frasa, dan (c) campur kode klausa. Adapun 28 data bentuk campur kode dalam film La Hila Donggo, campur kode berbentuk kata ada 17 data, frasa ada 7 data, dan klausa ada 4 data. 
Campur kode film La Hila Donggo tersebut terjadi karena faktor-faktor seperti, (a) faktor kebahasaan, (b) faktor kebiasaan, dan (c) faktor sikap penutur.

\section{Daftar Pustaka}

Astripona, M., Madeten, S. S., \& Amir, A. (2020). Alih Kode dan Campur Kode dalam Film Batas Karya Rudi Soedjarwo. Jurnal Pendidikan Dan Pembelajaran Khatulistiwa, 9 (2). Retrieved from https://jurnal.untan.ac.id.

Chaer, Abdul. \& Agustina, L. (2010). Sosiolinguistik: Perkenalan Awal. Jakarta: PT Rineka Cipta.

Chaer, A. (2008). Morfologi Bahasa Indonesia: Pendekatan Proses. Jakarta: Rineka Cipta.

Erinyanti, R, W, Syarifuddin, T, K., Datoh, K., \& E, Y. (2020). Linguistik Umum. Ponorogo: Uwais Inspirasi Indonesia.

Firman. (2016). Klasifikasi dan Analisis Klausa Bahasa Culambatu. Jurnal KANDAI, 12 (2), 187-204.

Hasan, M. (2015). Reviewing the Challenges and Opportunities Presented by Code Switching and Mixing in Bangla. Journal of Education and Practice, 6 (1), 103109. Retrieved from https://files.eric.ed.gov.

Holmes, J. (2001). An Introduction to Sociolinguistics. England: Pearson Education Limited.

Kridalaksana, H. (2011). Kamus
Linguistik. Jakarta: PT Gramedia Pustaka Utama.

Mahsun. (2005). Metode Penelitian Bahasa Tahapan Strategi, Metode, dan Tekniknya. Jakarta: PT. Raja Grafindo Persada.

Nababan, P. W. J. (1984). Sosiolinguistik Suatu Pengantar. Jakarta: PT. Gramedia Pustaka Utama.

Ohoiwutun, P. (2002). Sosiolinguistik: Memahami Bahasa Dalam Konteks Masyrakat dan Kebudayaan. Jakarta: Kesain Blance.

Padmadewi. (2014). Sosiolinguistik. Yogyakarta: Graha Ilmu.

R, Kunjana, R. (2001). Sosiolinguistik Kode dan Alih Kode. Yogyakarta: Pustaka Pelajar.

Suandi. (2014). Sosiolinguistik. Yogyakarta: Graha Ilmu.

Sumarsono. (2002). Sosiolinguistik. Yogyakarta: Pustaka Pelajar.

Wahyudin, A. (2012). Bilingualisme: Konsep dan Pengaruhnya Terhadap Individu. Seminar Internasional PIBSI XXXIV. Retrieved from http://staffnew.uny.ac.id.

Warsiman. (2014). Sosiolinguistik: Teori dan Aplikasi dalam Pembelajaran. Malang: Tim UB Press. 